\title{
RISK MANAGEMENT AND EFFICIENCY OF COOPERATIVES: A STUDY OF NEPALESE COOPERATIVES SOCIETIES
}

\author{
Gyanendra Prasd Paudel, Ph.D.*1 \\ ${ }^{1}$ Economics Faculty Member, National College (NIST), pgyanendrapd@gmail.com
}

\begin{abstract}
The people are achieving equal aims and goals have forming Cooperatives Society. It has made access to capital market for the people of poor, middle class, and illiterate in rural area whereas this became one of the wonderful business models in urban area. Risk management always has been included, but different stakeholders most critical of all risks faced by depository institutions. Though regulatory prerequisite imposed to Cooperative has not standard as imposed to banks by central bank, and the number of risks has been observed in this sector. Along with the horizontal and vertical growth of Cooperatives, it diluted the ethical practices, and resulted issues, such as adverse selection problem, lack of transparency and poor governance system. The study has analysis of risk management and efficiency of work and using in both quantitative and qualitative methods. A strong and prompt regulation should be imposed to eliminate such unfair practices. Credit risk management of Cooperative does not seem to be satisfactory so, concern authorities should select an appropriate credit risk management systems and management should give emphasis for credit risk management. Risk variables are significantly associated with financial performance, efficiency, and organizational factors. Credit Vulnerability Ratio of long-term solvency risk and credit default risk are $55 \%$ and $10 \%$ respectively and indicate the level of sensitiveness or danger of those variables during the day-to-day operation of Cooperatives to manage risk. A huge discrepancy on sizes of activities between the Cooperatives, unanimous regulatory direction for policy reform may not be effective for this sector.
\end{abstract}

\section{Keywords}

Cooperatives, credit risk, work efficiency and risk management

\section{JEL Classification}

D81 Criteria for Decision-Making under Risk and Uncertainty

P13 Cooperative Enterprises

DOI: https://doi.org/10.14311/bit.2021.02.02

Editorial information: journal Business \& IT, ISSN 2570-7434, CreativeCommons license (c) (i) published by CTU in Prague, 2021, http://bit.fsv.cvut.cz/ 


\section{Introduction}

Nepalese Cooperative movement began with the objectives of uplifting the Socio-economic status of the underprivileged rural people. Government of Nepal has established the Department of Cooperatives in 1953 to promote and assist the development of Cooperative. That could improve the living standard of people mainly in rural areas. Up to the 2020, there were 7,307,462 members in 29,886 Cooperatives and the cooperatives providing $18 \%$ of total banking services and contributes 4 $\%$ of total GDP of Nepal. As mainly poor and illiterate people from rural areas become members in a Cooperative society, they get access to capital with benefit sharing. However, some from highly recognized business houses mostly in urban areas also join Cooperatives. Up to the 2020, Cooperative Societies have 94,105 million rupees share capital, they have collected 477,961 million rupees as deposit, and they have provided 426,262 million rupees loan to their members (Department of Cooperatives, 2021). The sector has provided 88,309 persons direct employments and millions of indirect employments. A cooperative has increased due to capital access, risk sharing and Community support. Currently Cooperative has become a wonderful model of private business in urban area. This has encouraged a caution for ethical issues such as adverse selection problem, lack of transparency, misuse of funds, poor governance system, Due to those reasons, there is a precise need of awareness practices, and regulation of Cooperative norm has become more challenge.

The concept of Cooperative movement was initialed for rural economic development. Initially, Department of Cooperatives faced several problems such as lack of legislative framework, poor consciousness of the people towards Cooperatives, lack of educated human resources and unknown operational methods. But mushrooming growth took place of Cooperative after restoration of democracy in 1990. In 1992, new cooperative act was enacted, and democratic government of Nepal adopted liberal economic policy (Sharma, S. R.2006). Department of Cooperatives under Ministry of Cooperatives and Poverty Alleviation was regulating the overall functioning of Nepalese Cooperatives. Though, there are different division offices and training centers across the country increasing cooperatives density, few numbers of division office staff, poor institutional arrangements, lack of standard regulation system have caused cooperative regulations less effective. In this context, the Government of Nepal has identified Cooperative as a pure community organization with strong faith on self-sustaining and democratically governed (Bharadwaj, B. 2012).

The Cooperative practitioner and movement activist of Nepal, we have experienced that operation directed by Cooperative rules and regulations, and acts, rather dominated by attitudes of Board of Directors and core executives. Annual General Meeting (AGM) is the supreme body of cooperative society. Each member should actively participate in the AGM and business affairs of cooperatives. Attendance of members in AGM is very poor, and the board members and executive who take AGM as a burden, try to carry as only for legal formality. Fewer the cases, mostly board members do not have proper education and experience of Cooperatives. This has given some influential and assertive board members and managers to exploit member's fund. The management dominated by board directors pretends that the Cooperative is one of their own private businesses. Major portion of balance sheet of Cooperative is figured out by the loan and advance portfolio. Nepalese Cooperatives lack comprehensive risk management system, and credit risk is a major concern for lender worldwide as it is the most critical of all the risks faced by a depository institution.

The Cooperatives have establishing under act of saving and credit (SAC) and multipurpose Cooperative (MPC) as financial intermediaries in financial sector of Nepal. But they are neither financial institutions nor stock companies subjective to central bank's regulation. As financial intermediaries, they transfer financial surplus form surplus units to deficit units in financial sector. Cooperatives operate in a number of prioritized and marginal sectors of the economy such as a small farmer group, 
group of traders from same industry, or real estate traders, business house staffs, school/college staffs, community members, and so on. Those financial surpluses are further utilized for real investment, therefore, fund intermediation done by Cooperatives influences the number of economic indicators such as money supply, interest rate, inflation, investment, output, employment and living standard of people in marginal and priority sectors of economy (Mishkin, F. S.1992).

Though default on credit causes direct harm on firm, qualitative risk management focuses multiple aspect for making healthy and sustainable credit, and its risk management. Health of depository institutions is affected by a number of operational risks such as investment risk, solvency risk, liquidity risk, etc. Depository institutions are highly levered firm due to the presence of large portion of debt from deposit in its capital structure. Thus, Basel system has imposed in banking sector by regulatory authorities in number of countries such as Nepal. This helps to maintain a proper amount of adequate permanent capital in depository institution and prevent from firm default arises through debt default risk. But in case of cooperatives such provision is not applying, and it is crucial to investigate the capital adequacy of cooperative to seek long term insolvency strength of cooperative societies. Moreover, regulators and practitioners have advocated risk management as a governance system and transparency control practice applicable across all industries (ISO, 2009).

\section{Literature review}

According to Oxford Dictionary risk is a situation that could be dangerous or have a bad outcome (Oxford Dictionary, 2005). Risk refers to any event or issue that could occur and adversely impact the achievement of the organizations political, strategic, and operational objectives. Risk, then, is as much a potential missed opportunity as well as potential threat (UNESCO, 2010). Neither an intermediary nor a market maker will be perfectly hedged against all risks, and thus, its investors will bear an array of financial risks associated with the institution's activities. The risks borne by these financial institutions can be broken into five generic types: systematic, credit, counterparty, operational, and legal. The role of depository institutions has to improve the efficiency of financial markets. Depository institutions such as banks or Cooperatives were always faced with different types of risks that may have a potentially negative effect on their business. Risk-bearing has a natural aspect of banking service rendering firms, and without a doubt, profits have the reward for successful risk taking in business. Risk is exposed to of different degrees risk and different types. Risk has different meanings for various situations. No one can eliminate all risk, that's why we just try to minimize or reduce the negative effects of risk. Risk has the possibility that something harmful or undesirable may happen. This should include harm, injury or abuse to the organization's clients, volunteers, board members, employees, property or reputation (George, S.,\& Santomero,O. A. M, 1997).

\section{Types of risk}

The risk arises from the occurrence of some expected or unexpected events in the economy or the financial markets. Risk can also arise from staff oversight or internal dimension of firm, which destroy in asset values and, consequently, reduces the firms' intrinsic value. Risk can be listed in to credit risk, market risk, liquidity risk, operational risk, leverage risk, investment risk, etc. Again, all the risks can be decomposed into further sub-classes. There are arithmetically three types of risk, viz. market risk, credit risk, and operational risk to arrive at the overall risk estimate. Basel II etc. have outlined three types of risk: Market risk, Credit risk and Operational risk. Cooperative banks have identified five major risk categories as: credit risk, market risk, operational risk, reputational risk and liquidity risk (Constantinescu, C., Mattoo, A. \& Ruta, M. 2015). 
Market risk has the risk of change in value of asset with new systematic factor plays role in the market. Such types of risk hit mostly investment banker, and market price of stock of depositary institutions.

Market risk is loss due to on or off-balance sheet activities done banking service providing institutions. Market risk by its nature can be hedged but cannot be diversified away completely. Market risk is the risk originating in instruments and assets traded in well-defined markets. It is of two types; interest rates risk and risk of change in value of foreign currencies (Santomero, A. M. 1997).

The Basel Committee on Banking Supervision defines operational risk as the risk of loss resulting from inadequate or failed internal processes, people and systems or from external events. This definition includes legal risk but excludes strategic and reputation risk. Operational risk arises during the operation of activities of depository institutions. It includes a number of examples, such as a check incorrectly cleared, failure of the information technology system, incompetency or wrong posting of personnel, etc. Operational risk is losses include internal frauds such as theft or external frauds such as natural disasters or system related failures like machine related disruption, and other technological breakdowns. However, operational risk is harder to quantify and model than market and credit risks. Improvements in management information systems and computing technology have opened the way for improved operational risk measurement (Jalan, B. 2002).

In addition, market liquidity integrates key aspects of volume, time, and transaction costs. Liquidity risk relates to the depositary institution's ability to meet its continuing obligations, including financing its assets. It is the risk of loss record or of failure to accomplish estimated liquidity needs resulting from the incapacity of Cooperative banks to cope with the decrease of funding sources Liquidity risk is the risk of loss or failure to accomplish anticipated liquidity needs resulting from poor capability of banks to cope with the decrease of funding sources. Nikolaou has discussed three main liquidity concepts such as central bank liquidity (i.e. ability of the central bank to supply the liquidity needed to the financial system), market liquidity, and funding liquidity for aggregate financial system where banks are key player of economy, and central bank is a key regulator (Nikolaou, K. 2009).

Credit risk is the risk of record loss or failure to accomplish estimated profits due to non-fulfillment from the counterparty of its obligations stated in the contract. It is the potential that a contractual party will fail to meet its obligations in accordance with the agreed terms (Brown, K., \& Moles,P. (2011). Default risk is the likelihood of nonpayment of debt maturity. Failure of payment is declared when the scheduled payment was not made in a minimum period from the due date. Economic failure occurs when the economic value of the debtor's assets falls below the outstanding liabilities, which may not pay back debt. Exposure risk is risk of exposure quantifies uncertainty on the collection of amounts borrowed. If the loan is repaid under a firm contract program, the risk of exposure can be considered low or negligible. Unfortunately, this is not true for all lines of credit. If committed credit lines allow the debtor to access these lines whenever desired, according to his needs and a maximum limit set by the depositary institution so the depositary institution's risk exposure in this situation is considerable. Recovery risk is the risk of default in which recoveries are not expected. The extension of credit has always been at the core of banking operation and applied both to the loan and investment portfolio (Arunkumar \& Kotreshwar, 2006).

Credit risk has the single largest risk most depositary institutions or face and arises from the possibility that loans or bonds held by a depositary institution will not be repaid either partially or fully. Credit risk was often synonymous with default risk. Due to this risk, there is uncertainty of net-income and market value of equity arising from non-payment and delayed payment of principal and interest. Similarly, trading book credit risk arises due to a borrower's inability or unwillingness to discharge contractual obligations in trading contracts. This can result in settlement risk when one party to a deal pays money or delivers assets before receiving its own assets or cash, thereby, exposing it to potential 
loss. While a part of the credit risk is diversifiable, it cannot be eliminated completely. Credit risk means a risk resulted from inability of facility receiver in payment of the obligations to depositary institution and/or risk of non-returning of original and profit amount of investment which caused decrease in current value of firm's assets (Altman, E.,\& Saunders,A. 1998). It is also described in-depth in the upcoming topics.

\section{Risk Management}

UNESCO state that the risk management is the process of identifying, assessing, acting on, understanding, and communicating risk through a systematic approach. Reliable operation of a depository firm is founded by how risk management practices and procedures have been followed within organization (Shafiq, A.,\& Nasr,M. 2010). Though risk management is mostly term for the producers, within an organization, it has followed to protect itself, its staff, its clients, and its other stakeholders. It is an ongoing process and important part of planning of every business. The risk management should framework to reduce or eliminate the risk of certain kinds having a shock on the business (Six, K.,\& Kowalski E, 2005).

Risk management designs and implements effective control mechanisms in any organization that prevents and mitigates risks. Different risk management frameworks have been developed to effectively manage and mitigate unforeseen risks such as the Basel framework, PEARLS framework, etc. a risk management system composed of different guidelines aimed at efficiently managing risks. An effective risk management system should take into consideration all the critical risks involved in the process of a business. Management of risk in banking sector is affected by different factors such as technology, corporate governance, human capital and regulation (Ciuci Consulting, 2010).

\section{Process of Risk Management}

Depositary institutions or Cooperatives having banking role have to make banking system sound through diversify the risk. Therefore, it is necessary to deal with all kinds of risk related with banking for them. Risk management is main as well as important function of depositary institutions. It is the course of identifying risk and controlling them, i.e., keeping the risk at acceptance level. It contains identification, measurement, aggregation, planning and management, as well as monitoring of risk components within banking operational scope (OeNB \& FMA, 2004).

Risk Identification: It is the process of identifying risks that could potentially prevent the program, firm, or investment for achieving its objectives (Project Management Institute, 2008).

Risk Analysis: Risk analysis is the comprehensive function of risk assessment, risk characterization, risk communication, risk management, and policy relating to risk (Wikipedia). Risk analysis process consists of two components quantitative analysis and qualitative analysis. Quantitative analysis consists of analysis of financial and statistical data available from the day to day and record keeping system of any organization; the analysis of annual financial statements has a central position in this context. Qualitative analysis is done through the expert, experience and management skill of executives.

Risk Control: There must be an appropriate mechanism to regulate or guide the operation of the risk management system in the entire organization through a set of control devices. These can be achieved through a host of management processes such as assessing risk profile techniques regularly, analyzing internal and external audit feedback from the risk angle, and using it to activate control mechanisms (Oldfield, G. S.,\& Santomero, A. M, 1997). The credit union should establish and communicate control limits through policies, standards, and procedures that define responsibility and authority. The credit union should adjust these management tools if conditions or risk tolerances 
change. Further, the credit union should implement a process to authorize exceptions or changes to risk limits if warranted.

Risk Monitoring: The importance of monitoring risks is to make sure that they can be managed after identification. The SAC plays an increasingly important role in local financial economies. SAC or MPC has high competition for customers and resources with micro finance institutions and other commercial bank therefore they require effective and efficient risk control systems.

\section{Methods}

This study tracked neither of philosophical patterns purely nor ideological pattern. The philosophical postulation behind doing any rigorous study is based on researchers' background (Wolf, H., \&Pant, 2002). The research process usually starts with a broad area of qualitative and quantitative approach, but especially use in mixed methods. This study has mind set about his or her thought, norms, value, belief, etc. created through attributes of environment such as study, culture, work experience, people, socio-political dynamism, etc. where she or he inherited. It has an atomistic, ontological view of the world as comprising discrete, observable elements and events that interact in an observable, determined and regular manner (Collins, H., 2011). Positivist paradigm relates to business studies to a greater extent compared to other disciplines. This is because business relationships are just perceived as aggregation of relationships between individuals within and between firms and positivism is one of the most suitable approaches to study the nature of relationships.

The capital city, people from all around the country are living and working in Kathmandu. The demographic and economic heterogeneity gives resonance strata to do sampling, so Kathmandu district has selected as study area. It represents all varieties of Cooperatives such as small, medium and large, multipurpose (MPC) and saving and credit (SAC), women, agricultural, business, trade, etc. Studying the whole number of cooperatives is quite unrealistic.

Sample size is determined around 10 percent of total number of Cooperatives of Kathmandu assuming the year 2009 i.e., base sample year. Out of this sample size, 91 cooperatives are SAC, and remaining 35 are MAC. Sample is taken from the same sample for 5 years' time series secondary data from 2009 to 2013 for each cross-sectional observation. Year 2009 represents the Nepalese fiscal year 16th July 2008 to 15 th July 2009, and respective years represent in respective way. One questionnaire was filled by one respondent of each 126 sampled Cooperatives.

The study has used both primary and secondary surveyed data. The data collection procedures, objectives of data collection, data variables are collecting information by submitting structured questionnaire for respondent Cooperative society. Interviews were conducted with managing directors and senior staff, the questionnaire was categorized in six different parts: board information activities, operational activities, organizational setup, loan investment procedures, and risk and credit risk management.

\section{Discussion and Analysis}

This study has collected subjective and categorical respondent opinion. Categorical data has analyzed by frequency distribution and percentage distribution. Register or secondary data has used for quantitative in nature. This information has analyzed by using different tools and techniques.

Descriptive Analysis: Descriptive analysis uses descriptive statistics to describe the simple summaries about the data in a study. Descriptive statistics helps us to simplify a large amount of data in a sensible way. Descriptive analysis in this study has been done by using different statistical tools such as distribution analysis, measurement of central tendency, and dispersion. 
Financial Ratio Analysis: Financial ratios are mathematical comparisons of financial statement accounts or categories. These relationships between the financial statement accounts help investors, creditors, and internal firm management understand how well a Cooperative is performing and areas of need improvement. Ratios are just a raw computation of financial position and performance (Penman, S. 2009). Following three categories of ratio have been analyzed in chapter five and estimated as:

\section{Profitability Ratios}

Net Profit Margin (NPM): NPM is a ratio of profitability calculated as after-tax net income divided by total operating income which includes all interest income and noninterest income from different sources. It shows the amount of each rupee operating income from different sources left over after all expenses have been paid. A higher net profit margin means that a company is more efficient at converting operating revenues into actual profit (Thapa, K. 2012). In equation form it can be express as:

NPM $=\frac{\text { NetIncomeAfterTax }}{\text { OperatingIncome }}=\frac{\text { NetIncomeAfterTax }}{\text { InterestandNonInteresIncome }}$

Net Interest Margin (NIM): NIM is a measure of the difference between interest income generated by cooperatives and the amount of interest paid out to their lenders (e.g. deposits), relative to the amount of their interest-earning assets (Thapa, K. 2012). In mathematical expression it can be written as:

$\mathrm{NIM}=\frac{\text { NetInterestIncome }}{\text { EarningAssets }}=\frac{\text { InterestIncome-InterestExpenses }}{\text { Loan+OtherInvestment }}$

Return on Assets (ROA): ROA is the ratio of annual net income to average total assets of a business during a financial year. It measures efficiency of the business in using its assets to generate net income. ROA indicates the number of rupees earned on each rupee of assets. Thus higher values of return on assets show that business is more profitable (Brealey, R. A., Stewart,C.M.,\&Franklin,A., 2011). It can be estimated as:

ROA $=\frac{\text { NetIncomeAfterTax }}{\text { TotalAssets }}$

Return on Shareholders' Equity (ROE): ROE measures the ability of a firm to generate profits from its shareholders investments in a business firm. Investors want to see a high return on equity ratio because this indicates that the company is using its investors' funds effectively (Penman, S. 2009).

ROE $=\frac{\text { NetIncomeAfterTax }}{\text { TotalEquity }}=\frac{\text { NetIncomeAfterTax }}{\text { Sharecapital }+ \text { UndistributedProfit }+ \text { ReserveFund }}$

\section{Risk Measurement Ratios}

Liquidity Ratio (LR): LR is a measure of the solvency or liquidity of a business. It tells whether a cooperative has enough liquid assets to meet its financial obligations (i.e., deposit) as they become due. An LR that is too high may indicate investment in current assets that could otherwise be used to produce income. An LR that is too low means there may not be enough cash equivalent assets to meet financial obligations when they are due (Brealey, R. A., Stewart,C.M.,\&Franklin,A., 2011).

$\mathrm{LR}=\frac{\text { LiquidAssets }}{\text { TotalDeposit }}$ 
Capital Adequacy Ratio (CAR): CAR is used in commercial banking industry. Regulatory authorities keep an eye on the capital adequacy ratio of banks to ensure that they can absorb losses and meet capital requirements. Here, CAR is calculated as total capital other than deposit divided by total assets. This will give a gross estimation of long-term capital strength and credibility of cooperative to protect against risk arises from high degree of financial leverage.

$\mathrm{CAR}=\frac{\text { TotalPermanentCapital }}{\text { RiskWeightedAssets }}=\frac{\text { TotalAssets }- \text { Deposit }}{\text { TotalAssets }}$

Interest Spread (Spread): Spread is the interest rate charged by cooperative on loans to members minus the interest rate paid by Cooperative on deposits. This is the measure of profitability as well as risk. Higher degree of spread implies higher degree of earnings as well as selection of risky sector by Cooperatives.

$$
\begin{aligned}
\text { Spread } & =\text { Earning Rate }- \text { Paying Rate }=\frac{\text { Interest Income }}{\text { EarningAssets }}-\frac{\text { Interest Expenses }}{\text { PayingLiabilities }} \\
& =\frac{\text { Interest Income }}{\text { Loan+OtherInvestment }}-\frac{\text { Interest Expenses }}{\text { Deposit+OtherLiabilities }}
\end{aligned}
$$

Non-Performing Loan Ratio (NPL): NPL means nonperforming loans to total gross loans that it is the value of nonperforming loans divided by the total value of the loan portfolio (including nonperforming loans before the deduction of specific loan-loss provisions) of any cooperative NPL here is made provision for outstanding interest and principal amount due from borrower to total loan (Thapa, K., 2012). It measures the debt default rate of a Cooperative.

$\mathrm{NPL}=\frac{\text { Loan Loss Provision }}{\text { TotalLoan }}$

\section{Efficiency Ratios}

Assets Utilization Ratio (AU): AU ratio calculates the total revenue earned for every rupee of assets a cooperative owns. Increasing AU means the cooperative is being more efficient with each rupee of assets (Penman, S. 2009) it has,

$\mathrm{AU}=\frac{\text { OperatingIncome }}{\text { TotalAssets }}$

Credit to Deposit Ratio (CD): CD calculates the efficiency of deposit utilization. Since deposits are liabilities of cooperatives they have to utilize as far possible. CD ratio measures the efficiency and risk (Thapa, K., 2012).

$C D=\frac{\text { Credit }}{\text { Deposit }}$

\section{Financial Performance Model}

In financial performance model four regression equations are passed:

$$
\begin{aligned}
& C A R=\alpha+\beta 1 \text { ROA }+\beta 2 \text { NPM }+\beta 3 \text { NIM }+\beta 4 \text { ROE + ei ........................ }\left(A_{1}\right) \\
& \mathrm{NPL}=\alpha+\beta 1 \mathrm{ROA}+\beta 2 \mathrm{NPM}+\beta 3 \mathrm{NIM}+\beta 4 \mathrm{ROE}+\text { ei ......................... }\left(\mathrm{A}_{2}\right) \\
& L R=\alpha+\beta 1 \text { ROA + } \beta 2 \mathrm{NPM}+\beta 3 \mathrm{NIM}+\beta 4 \mathrm{ROE}+\text { ei } \ldots \ldots \ldots \ldots \ldots \ldots \ldots \ldots . . . . . . . .\left(A_{3}\right) \\
& \text { Spread }=\alpha+\beta 1 \text { ROA }+\beta 2 \mathrm{NPM}+\beta 3 \mathrm{NIM}+\beta 4 \mathrm{ROE}+\text { ei } \ldots \ldots \ldots \ldots \ldots \ldots . . . . . \quad\left(\mathrm{A}_{4}\right)
\end{aligned}
$$


Where, ROE, NPM, NIM and ROA are profitability measurement factors. In hypothesis testing, higher CAR variable implies less risky but also expected to generate low degree of ROE by multiplying ROA by lower equity multiplier (i.e., equity multiplier = total assets/equity). Thus, it is assumed to be positive relationship between CAR and profitability ratio. NPL is absolute risk; means this type of risk taking does not increase the profit but is the results from poor management of credit portfolio. Thus, there must be negative relationship between LR and profitability ratio. LR is a measure of liquidity risk, higher the liquidity, lower the risk but also lower the profitability due to the opportunity cost of liquidity. Thus, there must be negative relationship between LR and profitability ratio. Spread measures the investment risk. Higher spread gives higher net interest income that implies the positive relationship between investment risk and profitability.

From some of the past findings we can say that sound credit and other risk management practices result lower default in loan investment that further results to higher interest income and profitability of depository institutions. This will also increase the vital of absorbing loan default loss. Profitability and financial health can be adversely affected by risk. In contrast of that observed credit risk management does have positive effects on profitability. Furthermore, Credit risk has been affected the profitability of the Nigerian banks negatively. For this reason, it is important to examine credit policies today.

\section{Efficiency Model}

In risk versus efficiency model four regression equations are passed as:

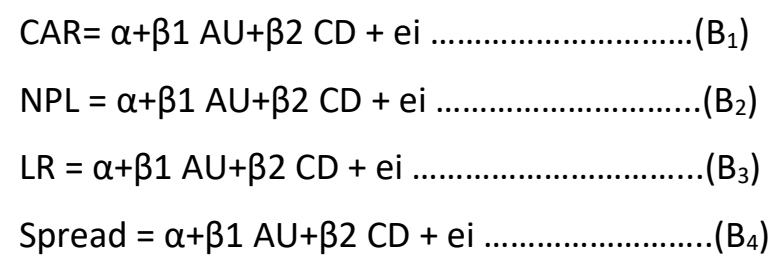

Where, $A U$ and $C D$ are efficiency measurement factors. The relation is defined to seek the efficiency influences on risk level of cooperative.

\section{Organizational Factors Model}

In organizational factors model four regression equations are passed as:

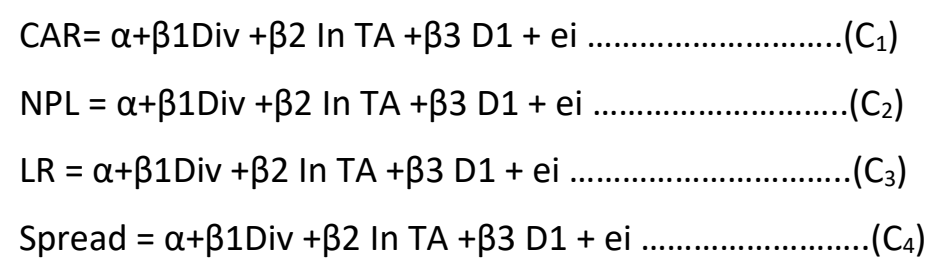

Where, Div, In TA and D1 are the organizational factor measurement variables. Div is dividend rate, InTA is natural logarithm of total assets and measure the size and D1 is the dummy variable of types, i.e., D1=1 if SAC else 0 . The relation is defined to seek the influences of dividend distribution, size and types on risk level of cooperative. 


\section{Ratio Analysis}

A financial ratio (or accounting ratio) analysis is a process of comparing scale of two selected numerical values taken from a venture's financial statements. Financial ratios may be used by managers within a firm, by current and potential owners of a firm, by competitors, by researchers, and by a firm's creditors. Financial analysts use financial ratios to compare the strengths and weaknesses in various companies. Ratios can be expressed as a decimal value, such as 0.10 , or given as an equivalent percent value, such as 10 percent. Some ratios are usually quoted as percentages, especially ratios that are usually or always less than 1 , while others are usually quoted as decimal numbers, especially ratios that are usually more than 1 . Financial ratios are categorized according to the financial aspect of the business which the ratio measures. Ratios generally are not useful unless they are benchmarked against something else, like past performance or another firm. Financial ratios allow for comparisons between firms, between industries, between different time periods for one firm, between a single firm and its industry average. Thus, the ratios of firms in different industries, which face different risks, capital requirements, and competition, are usually hard to compare 1 . For this study, profitability ratios, risk ratios, efficiency ratios have calculated and analyzed for Nepalese cooperatives, and descriptive statistics of those ratios are presented as:

\section{Profitability Ratios}

Profitability ratios measure a cooperative's ability to generate earnings relative to total operating revenues, assets and equity. Common examples of profitability ratios those this study has calculated and presented here include return on operating revenues i.e., net profit margin (NPM), return on investment or assets (ROA), return on equity (ROE) and net interest margin (NIM). All of these ratios indicate how well a cooperative is performing in generating profits or revenues relative to a certain aspect. Different profitability ratios provide different useful insights into the financial health and performance of a cooperative. For example, NIM and NPM ratios tell how well the cooperative is managing its expenses. ROA tells how well the cooperative is using capital employed to generate returns. ROE tells whether the cooperative is generating enough profits for its shareholders. For most of these ratios, a higher value is desirable. Here, from entire sample some, cooperatives are receiving government and other agency fund as subsidies in free for priority sector mobilization and thus, abnormal results such as NIM of $72.27 \%$, ROE of $166.79 \%$, etc. have observed but all of those earnings are not subject to dividend distribution.

Descriptive statistics of profitability ratios of entire sample, by categorizing in to saving and SAC and MPC, and for entire period from 2009 to 2013 of Nepalese Cooperative society are presented in table 1. Drawn statistics shows average ROE of the sample is $5.20 \%$ and suggests in average cooperative shareholders are receiving 5.2\% return (i.e., net profit) on their investment or shareholder fund. Standard deviation of ROE is $22.21 \%$ that shows in average ROE of cooperative may deviate by $\pm 22.21 \%$ in estimation from given set of data. The maximum ROE of the industry within sample is $166.15 \%$ and minimum ROE score of the industry within sample is $-315.79 \%$ having range of $481.94 \%$ score. This shows the much variation of the ROE in cooperative society of Nepal. The earning pattern shows by ROE is much fluctuating that might has created more risk on cooperative society of Nepal. The median score divides the data into two parts, and the ROE score is 5.07\% for entire sample. If we compare the descriptive scores of SAC and MPC, SAC has higher ROE than MPC but also higher fluctuation of earnings. This suggests MPC operating less risky than SAC. Similarly, descriptive statistics of ROA, NIM, and NPM are presented in the same table. 
Table 1: Profitability Ratios of Entire Sample (in percent)

\begin{tabular}{lrrrrrrr|rrrrrr}
\hline & \multicolumn{4}{c}{ ROE } & \multicolumn{4}{c}{ NPM } & \multicolumn{3}{c}{ ROA } & \multicolumn{4}{c}{ NIM } \\
\cline { 2 - 14 } & Total & \multicolumn{1}{c}{ SAC } & MPC & \multicolumn{1}{l}{ Total } & \multicolumn{1}{c}{ SAC } & MPC & Total & SAC & MPC & Total & SAC & MPC \\
\hline Avg. & 5.20 & 5.23 & 5.12 & 4.53 & 3.36 & 7.80 & 0.82 & 0.69 & 1.17 & 4.97 & 5.30 & 4.06 \\
Md. & 5.07 & 4.73 & 7.68 & 6.25 & 5.81 & 10.16 & 0.81 & 0.72 & 1.28 & 4.07 & 4.26 & 3.49 \\
SD & 22.21 & 22.98 & 20.00 & 29.02 & 32.14 & 17.22 & 2.04 & 1.93 & 2.29 & 5.91 & 5.14 & 7.60 \\
Max & 166.15 & 166.15 & 35.26 & 55.37 & 50.57 & 55.37 & 6.72 & 6.70 & 6.72 & 72.27 & 38.41 & 72.27 \\
& & & & & & & & & - & & & \\
Min & -315.79 & -315.79 & -102.19 & -493.33 & -493.33 & -59.42 & -17.92 & -17.92 & 7.00 & -9.38 & -9.38 & -7.03 \\
N & 539 & 397 & 142 & 539 & 397 & 142 & 538 & 396 & 142 & 539 & 397 & 142 \\
\hline
\end{tabular}

(Avg.=Arithmetic average, Md.=Median, SD=Standard deviation, Max=Maximum, Min=Minimum, $\mathrm{N}=$ No of Observations)

Table 2: Profitability Ratios of 2009-13 (in percent)

\begin{tabular}{|c|c|c|c|c|c|c|c|c|c|c|c|c|c|}
\hline & \multicolumn{3}{|c|}{ ROE } & \multicolumn{3}{|c|}{ NPM } & \multicolumn{3}{|c|}{ ROA } & \multicolumn{3}{|c|}{ NIM } \\
\hline & & Total & SAC & MPC & Total & SAC & MPC & Total & SAC & MPC & Total & SAC & MPC \\
\hline \multirow{6}{*}{$\begin{array}{l}0 \\
0 \\
9\end{array}$} & Avg. & 5.94 & 4.06 & 11.36 & 0.99 & -3.52 & 14.02 & 0.58 & 0.23 & 1.57 & 5.39 & 5.36 & 5.46 \\
\hline & Md. & 4.12 & 3.36 & 11.23 & 6.16 & 4.60 & 14.37 & 0.60 & 0.53 & 1.87 & 4.01 & 4.15 & 3.20 \\
\hline & SD & 16.83 & 18.32 & 9.89 & 52.09 & 59.48 & 12.04 & 1.96 & 1.83 & 2.01 & 8.61 & 5.75 & 14.03 \\
\hline & Max & 100.00 & 100.00 & 31.39 & 35.90 & 35.89 & 35.90 & 6.35 & 3.33 & 6.35 & 72.27 & 28.66 & 72.27 \\
\hline & Min & -74.00 & -74.00 & -10.03 & 493.3 & 493.3 & -11.86 & 8.95 & -8.95 & -5.05 & -3.60 & -3.60 & -3.20 \\
\hline & $\mathrm{N}$ & 101 & 75 & 26 & 101 & 75 & 26 & 100 & 74 & 26 & 100 & 74 & 26 \\
\hline \multirow{6}{*}{$\begin{array}{l}2 \\
0 \\
1 \\
0\end{array}$} & Avg. & 8.65 & 8.73 & 8.45 & 5.23 & 3.68 & 9.35 & 0.74 & 0.54 & 1.27 & 5.05 & 5.34 & 4.28 \\
\hline & Md. & 4.95 & 4.28 & 8.85 & 5.80 & 5.19 & 8.19 & 0.81 & 0.64 & 0.93 & 4.01 & 4.20 & 3.76 \\
\hline & SD & 23.20 & 26.52 & 10.44 & 19.68 & 21.11 & 14.79 & 2.56 & 2.69 & 2.12 & 4.81 & 4.63 & 5.27 \\
\hline & Max & 166.15 & 166.15 & 26.32 & 37.69 & 32.70 & 37.69 & 5.54 & 4.64 & 5.54 & 24.29 & 22.75 & 24.29 \\
\hline & Min & -71.18 & -71.18 & -25.61 & 133.0 & 133.0 & -40.66 & 17.9 & -17.9 & 4.88 & -4.34 & -3.39 & -4.34 \\
\hline & $\mathrm{N}$ & 106 & 77 & 29 & 106 & 77 & 29 & 106 & 77 & 29 & 106 & 77 & 29 \\
\hline \multirow{6}{*}{$\begin{array}{l}2 \\
0 \\
1 \\
1\end{array}$} & Avg. & 6.47 & 6.75 & 5.69 & 7.76 & 7.91 & 7.34 & 1.10 & 1.09 & 1.13 & 5.61 & 6.06 & 4.32 \\
\hline & Md. & 5.55 & 5.48 & 7.31 & 6.57 & 6.49 & 8.62 & 0.94 & 0.91 & 1.17 & 4.68 & 5.18 & 3.99 \\
\hline & $S$ & 9.43 & 7.71 & 13.27 & 11.77 & 9.17 & 17.34 & 1.63 & 1.32 & 2.33 & 5.12 & 5.25 & 4.58 \\
\hline & Max & 33.88 & 25.56 & 33.88 & 55.37 & 50.57 & 55.37 & 6.72 & 6.70 & 6.72 & 25.66 & 25.66 & 14.80 \\
\hline & Min & -28.99 & -16.22 & -28.99 & 44.68 & 10.78 & -44.68 & 4.03 & -2.85 & -4.03 & -9.38 & -9.38 & -4.23 \\
\hline & $\mathrm{N}$ & 111 & 82 & 29 & 111 & 82 & 29 & 111 & 82 & 29 & 111 & 82 & 29 \\
\hline \multirow{6}{*}{$\begin{array}{l}2 \\
0 \\
1 \\
2\end{array}$} & Avg. & 1.38 & 1.66 & 0.58 & 3.17 & 3.02 & 3.61 & 0.81 & 0.79 & 0.85 & 4.53 & 4.95 & 3.33 \\
\hline & Md. & 5.43 & 5.30 & 7.62 & 6.20 & 5.48 & 10.28 & 0.82 & 0.81 & 1.33 & 4.15 & 4.28 & 3.01 \\
\hline & SD & 34.78 & 37.20 & 27.38 & 30.93 & 33.62 & 22.10 & 2.16 & 1.93 & 2.76 & 4.53 & 4.24 & 5.15 \\
\hline & Max & 35.26 & 32.56 & 35.26 & 30.20 & 30.20 & 28.26 & 6.60 & 6.60 & 4.59 & 21.18 & 21.18 & 17.51 \\
\hline & Min & -315.8 & -315.8 & -79.66 & 282.6 & 282.6 & -59.42 & 9.85 & -9.85 & -7.00 & -7.35 & -7.35 & -7.03 \\
\hline & $\mathrm{N}$ & 111 & 82 & 29 & 111 & 82 & 29 & 111 & 82 & 29 & 111 & 82 & 29 \\
\hline 2 & Avg. & 3.78 & 5.08 & 0.14 & 5.22 & 5.19 & 5.30 & 0.84 & 0.76 & 1.06 & 4.35 & 4.81 & 3.04 \\
\hline 0 & Md. & 4.97 & 5.30 & 4.24 & 6.16 & 6.06 & 8.18 & 0.81 & 0.78 & 0.86 & 3.50 & 3.93 & 3.43 \\
\hline 1 & SD & 17.77 & 12.04 & 28.23 & 12.74 & 10.91 & 17.09 & 1.77 & 1.58 & 2.24 & 5.82 & 5.72 & 6.02 \\
\hline 3 & Max & 30.88 & 30.88 & 30.70 & 31.81 & 24.64 & 31.81 & 6.16 & 4.55 & 6.16 & 38.41 & 38.41 & 18.06 \\
\hline
\end{tabular}




\begin{tabular}{lrrrrrrrrrrrr}
\hline & & & & - & - & & - & & & & \\
Min & -102.2 & -59.96 & -102.2 & 46.54 & 35.25 & -46.54 & 4.81 & -4.81 & -3.61 & -6.91 & -5.62 & -6.91 \\
$\mathrm{~N}$ & 110 & 81 & 29 & 110 & 81 & 29 & 110 & 81 & 29 & 111 & 82 & 29 \\
\hline
\end{tabular}

(Avg.=Arithmetic average, Md.=Median, SD=Standard deviation, Max=Maximum, Min=Minimum, $\mathrm{N}=$ No of Observations)

The table 2 presents year-wise descriptive statistics of entire sample, SAC and MPC for 2009 to 2013. The table shows Standard deviation of NIM is 5.12\% for 2011 and shows in average NIM of cooperative may deviate by $\pm 5.12 \%$ in estimation from given set of data. The maximum NIM of the industry within sample is $25.66 \%$ and minimum NIM score with in sample is $-9.38 \%$ having range of $35.04 \%$ score and shows the much difference of NIM in cooperative society of Nepal. Drawn statistics also shows average ROA of the sample is $0.81 \%$ for 2012 and suggests in average cooperative shareholders are receiving $0.81 \%$ return (i.e., net profit) on investment or on total assets. Standard deviation of ROA is $2.16 \%$ that shows in average ROA of cooperative may deviate by $\pm 2.16 \%$ in estimation from given set of data. From same table, statistics shows average NPM of the sample is $5.22 \%$, and suggests in average cooperative shareholders are receiving $5.22 \%$ return (i.e., net profit) on cooperative total operating revenues for 2013. Standard deviation of NPM is $12.74 \%$ that shows in average NPM of cooperative may move away by $\pm 12.74 \%$. The maximum NPM of the industry for 2013 is $31.81 \%$ and minimum NPM score of the industry within sample is $-46.54 \%$. Average NIM of the sample is $4.35 \%$, and Standard deviation of NIM is $5.82 \%$ that shows in average NIM of cooperative may deviate by $\pm 5.82 \%$ in estimation from given set of data for 2013. The maximum NIM of the industry within sample is $38.41 \%$ and minimum NIM score of the industry within sample is $-6.91 \%$ having range of $45.32 \%$ score.

\section{Risk Measurement Ratios:}

Risk measurement ratios measure a cooperative risky behavior or risk taking during its day-to-day operation. These ratios assess the level of a cooperative to tolerate possible fluctuations on earnings, profits or cash flows, often the quality of activities. They highlight how effectively the risk of a cooperative is being taken and managed. Common examples of those risk measurement ratios this study has estimated and presented here include liquidity ratio (LR), capital adequacy ratio (CAR), net interest spread (Spread) and nonperforming loan to total loan ratio (NPL). Higher LR and CAR correspond risk managing, unlike that lower degree of NPL and Spread correspond the risk is managing.

The descriptive statistics of risk measurement ratios of entire sample, SAC and MPC and for entire period from 2009 to 2013 of Nepalese cooperative society are presented in table 35. Drawn statistics shows average LR of the sample is $20.40 \%$ and suggests in average cooperative has $20.40 \%$ liquid assets to pay day to day liquidity demanded by depositor. Higher amount of LR stands higher ability of paying debt but low degree of efficiency and profitability due to opportunity cost of liquidity. Standard deviation of $L R$ is $14.54 \%$ that shows in average LR of cooperative has deviated by $\pm 14.54 \%$ in estimation from given set of data. Maximum LR of the industry within sample is $136.98 \%$ and Minimum LR score of the industry within sample is $1.34 \%$ having range of $135.64 \%$ score. The median score is partition value into two equal upper and lower parts of data. For entire sample, $50 \%$ of cooperatives are operating above $17.07 \%$ LR scores. If we compare the descriptive scores of SAC and MPC, SAC has higher LR than MPC. This suggests MPC operating riskier than SAC.

From the table 4, year-wise statistics shows average Spread of the sample is $5.56 \%$ for 2011 and suggests average difference in earning and paying rate of cooperative is $5.56 \%$. Standard deviation shows in average Spread of cooperative may deviate by $4.87 \%$ either in positive or in negative direction. The maximum Spread of the industry within sample is $22.72 \%$, and minimum Spread score of the industry within sample is $-8.75 \%$. This suggests cooperatives of Nepal are taking much risky decision while making borrowing and lending activities. The median score divides the data into two parts, and the Spread score is $5.10 \%$ for entire sample. It shows average LR of the sample is $19.81 \%$ for 2013 and suggests in average cooperative has 19.81\% liquid assets to pay day to day liquidity 
demanded by depositor. Drawn statistics also shows average CAR of the sample is $22.89 \%$ for 2013 and suggests in average cooperatives' long term or permanent capital is $22.89 \%$ total assets. The standard deviation of CAR is $13.67 \%$ that shows in average CAR of cooperative may deviate by $\pm 13.67 \%$ for estimated mean. In comparison, SAC has lower CAR than MPC and lower fluctuation for 2013.

Table 3: Risk Measurement Ratios of Entire Sample (in percent)

\begin{tabular}{|c|c|c|c|c|c|c|c|c|c|c|c|c|}
\hline & \multicolumn{3}{|c|}{ LR } & \multicolumn{3}{|c|}{ CAR } & \multicolumn{3}{|c|}{ Spread } & \multicolumn{3}{|c|}{ NPL } \\
\hline & Total & SAC & MPC & Total & SAC & MPC & Total & SAC & MPC & Total & SAC & MPC \\
\hline Avg. & 20.40 & 20.75 & 19.50 & 24.08 & 23.95 & 24.41 & 5.29 & 5.62 & 4.34 & 4.82 & 3.13 & 6.43 \\
\hline Md. & 17.07 & 17.47 & 16.76 & 20.31 & 20.30 & 20.56 & 4.59 & 4.72 & 4.07 & 3.49 & 2.21 & 5.15 \\
\hline SD & 14.54 & 14.64 & 14.28 & 14.78 & 14.40 & 15.75 & 6.44 & 5.77 & 7.98 & 3.63 & 2.64 & 3.77 \\
\hline Max & 136.98 & 136.98 & 89.72 & 94.38 & 94.38 & 89.05 & 71.48 & 60.76 & 71.48 & 14.77 & 9.15 & 14.77 \\
\hline Min & 1.34 & 1.34 & 2.31 & -17.21 & -2.71 & -17.21 & -40.29 & -13.71 & -40.3 & 0.05 & 0.05 & 1.71 \\
\hline $\mathrm{N}$ & 608 & 438 & 170 & 612 & 441 & 171 & 539 & 397 & 142 & 47 & 23 & 24 \\
\hline
\end{tabular}

(Avg.=Arithmetic average, Md.=Median, SD=Standard deviation, Max=Maximum, Min=Minimum, $\mathrm{N}=$ No of Observations)

Table 4: Risk Measurement Ratios of 2009-13 (in percent)

\begin{tabular}{|c|c|c|c|c|c|c|c|c|c|c|c|c|c|}
\hline & \multicolumn{3}{|c|}{ LR } & \multicolumn{3}{|c|}{ CAR } & \multicolumn{3}{|c|}{ Spread } & \multicolumn{3}{|c|}{ NPL } \\
\hline & & Total & SAC & MPC & tal & $A C$ & MPC & tal & SAC & MPC & Total & SAC & MPC \\
\hline & Avg. & 0.53 & 0.64 & 20.25 & 5.46 & 5.24 & 23.39 & 5.28 & 5. & 4.16 & 6.37 & & \\
\hline 2 & Md. & 56 & .56 & 17.79 & .31 & .25 & 10 & 05 & & & & & \\
\hline 0 & SD & 1 & 3.88 & & .44 & & & 83 & & & 02 & & \\
\hline 0 & Max & 136.98 & 6.98 & 56.06 & 89.05 & 76.99 & 89.05 & 71.48 & & & .77 & 35 & \\
\hline \multirow[t]{3}{*}{9} & Min & 1.34 & 1.34 & 3.65 & 17.21 & -1.48 & -17.2 & -40.3 & -3.45 & -40.29 & .40 & 35 & 40 \\
\hline & $\mathrm{N}$ & 108 & 78 & 30 & 113 & 82 & 31 & 100 & 74 & 26 & 5 & & \\
\hline & $A v \xi$ & 8 & 05 & .38 & 3.62 & 23.69 & 46 & 5.07 & & & 18 & 5.27 & \\
\hline 2 & Md. & & & & & 1.44 & & & & & 74 & & \\
\hline & SD & 2 & 1 & & 2 & 17 & & 4.02 & & & 83 & & \\
\hline 1 & Max & 118.42 & 18.42 & 73.17 & 69.80 & 69.80 & 64 & 21.97 & & & 10.01 & .24 & \\
\hline \multirow[t]{3}{*}{0} & Min & 55 & .80 & 5 & -2.71 & -2.71 & 4.42 & -2.11 & 74 & 11 & .04 & 29 & \\
\hline & $\mathrm{N}$ & & 7 & 3 & 1 & 86 & 35 & 106 & & & - & & \\
\hline & $A v$ & & .58 & & 4 & .72 & & O & & & 28 & & \\
\hline 2 & Md. & & & & & 1.86 & & 5.10 & & & 12 & 52 & \\
\hline & SD & & & & 14.61 & 15.56 & & 4.87 & & & 1 & & \\
\hline 1 & Max & 14 & 61 & 72. & 94.38 & 4.38 & 59.95 & 22.72 & 2 & & 15 & 14 & \\
\hline \multirow[t]{3}{*}{1} & Min & & & & & 6.11 & 5.85 & -8.7 & -8. & -4. & .21 & 52 & \\
\hline & $\mathrm{N}$ & & & & & 91 & 35 & $\perp$ & & & 5 & & \\
\hline & Avg. & & & & & 22.17 & & & & & 43 & 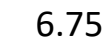 & \\
\hline 2 & Md. & & & & 55 & 18.95 & 22.03 & 5.09 & 5 & 1 & 97 & 5. & \\
\hline & SD & & 0 & 18 & 72 & 2.53 & 20 & 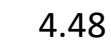 & & & 0 & & \\
\hline 1 & Max & 89.7 & 6 & 89. & 14 & 64.14 & 61.52 & 21.00 & 0 & & .85 & 12 & \\
\hline \multirow[t]{2}{*}{2} & Min & & & & & 2.69 & 6.62 & -7.35 & -7.35 & & .05 & 2.33 & \\
\hline & $\mathrm{N}$ & & & & 126 & 91 & 35 & 11 & & 25 & 9 & 6 & 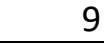 \\
\hline & $\Delta v$ & & & & 2.89 & 2.16 & 24.80 & 5. & & & 31 & 47 & \\
\hline & & & & & & 31 & & & & & & & \\
\hline & & & & & & 12.80 & & & & & & & \\
\hline 3 & Max & 8.19 & 3.19 & 59.56 & 30.78 & 74.55 & 80.78 & 38.35 & 38.35 & 17.4 & .73 & 8.75 & 7.7 \\
\hline
\end{tabular}




\begin{tabular}{lrrrrrrrrrrrr}
\hline Min & 1.56 & 1.56 & 3.27 & 3.55 & 3.55 & 5.47 & -13.7 & -13.7 & -6.66 & 0.82 & 1.71 & 0.82 \\
$\mathrm{~N}$ & 126 & 91 & 35 & 126 & 91 & 35 & 111 & 82 & 29 & 6 & 6 & 6 \\
\hline
\end{tabular}

(Avg.=Arithmetic average, Md.=Median, SD=Standard deviation, Max=Maximum, Min=Minimum, $\mathrm{N}=$ No of Observations)

\section{Efficiency Ratios:}

Efficiency Ratio measures how efficiently a cooperative utilizing its valuable resources such as assets, liquidity, human capital etc. These ratios assess efficiency or productivity level of a cooperative to produce higher earnings, profits or cash flows, or lower risky behavior. Common examples of those efficiency ratios this study has estimated and presented here include assets utilization ratio (AU) which is also called total assets turnover ratio or activity ratio and credit to deposit ratio (CD).

Table 5: Efficiency Ratios of Entire Sample (in percent)

\begin{tabular}{lrrr|rrrr}
\hline & \multicolumn{3}{c}{ AU } & \multicolumn{3}{c}{ CD } \\
\cline { 2 - 8 } & Total & \multicolumn{2}{c}{ SAC } & MPC & Total & SAC & MPC \\
\hline Avg. & 13.61 & 13.62 & 13.60 & 99.27 & 100.35 & 96.47 \\
Md. & 13.25 & 13.35 & 12.72 & 95.81 & 97.69 & 92.44 \\
SD & 3.56 & 3.31 & 4.21 & 24.68 & 23.96 & 26.32 \\
Max & 42.62 & 30.19 & 42.62 & 196.27 & 196.27 & 189.61 \\
Min & 1.81 & 1.81 & 7.36 & 41.30 & 41.30 & 45.22 \\
N & 539 & 397 & 142 & 607 & 438 & 169 \\
\hline
\end{tabular}

(Avg.=Arithmetic average, Md.=Median, SD=Standard deviation, Max=Maximum, Min=Minimum, $\mathrm{N}=$ No of Observations)

The descriptive statistics of efficiency ratios of entire sample, SAC and MPC polling entire sample data of 2009 to 2013 are presented in table 5. The statistics show average AU of the sample is $13.61 \%$ and suggests in average cooperative has generated $13.61 \%$ total operating revenue of total assets. Higher amount of AU stands higher ability of generating revenue, and thus, higher degree of efficiency and profitability. Standard deviation of $A U$ is $3.56 \%$ that shows in average AU of cooperative has deviated by $\pm 3.56 \%$ in estimation from given set of data. A maximum AU of the industry within sample is $42.62 \%$ and minimum AU score of the industry within sample is $1.81 \%$ having range of $40.79 \%$ score. Drawn statistics also shows average CD of the sample is $99.27 \%$ and suggests in average cooperative of Nepal are utilizing it's near to $100 \%$ deposit to credit for revenue generation. A maximum CD of the industry within sample is $196.27 \%$ and Minimum CD score of the industry within sample is $41.30 \%$ having range of $154.97 \%$ score.

\section{Conclusion}

The Cooperatives do not have separate risk management department. Nearly ninety percent of respondent opine that significantly large amount of loan, longer credit repayment period, no risk control mechanism, and no proper documentation in loan file as some of the serious problems for solution. Risk variables are significantly associated with financial performance, efficiency and organizational factors. NPM and ROE influence CAR negatively and positively respectively as expected. Big cooperatives do not have adequate long-term capital and in higher degree of solvency risk. NPM and ROA positively whereas NPM is negatively associated with LR suggesting possible reduction in liquidity risk by holding adequate liquidity but optimize the tradeoff between LR \& NPM. The causation on LR from NIM and ROA is inconsistent. Cooperative having adequate capital can supply more loan even if deposit collection is not much suggesting higher CD ratio has higher permanent. NIM is 
positively associated with investment risk. Cooperatives should balance tradeoff between risk, efficiency and return while taking investment risk since AU significantly affects spread. The management needs to work seriously in order to reduce debt default so that it could insure healthy credit management. Most sensitive operational scope is leverage risk having CVR of 60 percent. Commercial Banks in Nepal apply BASEL system to manage long term solvency and leverage risk. This indicates practitioner to apply appropriate long term solvency management technique to ensure healthy operation that credit default risk could be reduced through proper credit rationing.

The management and control committee needs to emphasize risk management and practical implementation. Since almost all respondents recognized the need for credit information center, managements of Cooperatives should use credit information from credit information center to seek the past record of borrower and to avoid the credit duplication risk. Members and board of directors should not be profit oriented in the short run, but they should seek the progress of cooperatives in long run. A few cooperatives follow PEARLS system and 5 Cs principle, but it is important to all. Illegal managerial practices such as assigning executive role to more than one board member, assigning managing director and chairman of board as chief of loan committee, providing loan to outsider through temporary membership, providing significantly huge amount of loan to the single member, charging 1 to 2 percent service fee of loan should be avoided are risk of Cooperatives.

\section{References}

[1] Arunkumar \& Kotreshwar. (2006). Risk Management in Commercial Banks (A Case Study of Public and Private Sector Banks). Jurnal Akuntansi Diakses.tanggal.

[2] Bharadwaj, B. (2012). Roles of Cooperatives in Poverty Reduction: A Case of Nepal. Administration and Management Review Vol. 24, No. 1, January, 2012, Page 120-129.

[3] Mishkin, F. S.(1992). Financial Markets, Institution, and Money, Harper Colins College Publishers, New York.

[4] Brealey, R. A., Stewart,C.M.,\&Franklin,A. (2011). Principles of Corporate Finance. Tenth Edition McGrawHill/Irwin. Chap. 28, Pp. 704 - 724.

[5] Brealey, R. A., Stewart,C.M.,\&Franklin,A. (2011). Principles of Corporate Finance. Tenth Edition McGrawHill/Irwin. Chap. 28, Pp. 704 - 724.

[6] Brown, K.,\& Moles,P. (2011). Credit Risk Management Edinburgh Business School, Heriot-Watt University, Edinburgh EH14 4AS, United Kingdom.

[7] Ciuci Consulting. (2010). Getting the Basic Right in Risk Management for Banks in Developing Countries.

[8] Collins, H. (2011). Creative Research: The Theory and Practice of Research for the Creative Industries. AVA Publications.

[9] Constantinescu, C., Mattoo, A. \& Ruta, M. (2015) .The Global Trade Slowdown: Cyclical or Structural? IMF Working Paper. https://www.imf.org/external/ pubs/ft/wp/2015/ wp1506.pdf

[10] COSO. (2004). Enterprise Risk Management Framework. New York, NY: American Institute of Certified Public Accountants.

[11] Department of Cooperatives. (2021). Cooperative Jhalak. New Baneswor, Kathmandu.

[12] Fan, L.,\& Yijun, Z. (2014).The Impact of Credit Risk Management on Profitability of Commercial Banks:A Study of Europe. UMEA School of Business and Economics.

[13] Goyal, K. A.,\& Agrawal,S.(2010). Risk Management in Indian Banks: Some Emerging Issues. Int. Eco. J.Res., 2010 1(1) 102-109.

[14] George, S.,\& Santomero,O. A. M. (1997). The Place of Risk Management in Financial Institutions.

[15] ISO.(2009).International Organization for Standardization. 31000:2009 Risk Management - Principles and Guidelines. Geneva.

[16] Jalan, B. (2002). Indian Banking and Finance: Managing New Challenges, Addressed Delivered at the Twenty third Bank Economist Conference at Kolkata, January.

[17] Muritala, T. A.,\& Taiwo,S. T. (2013). Credit Management Spur Higher Profitability Evidence from Nigerian Banking Sector. Journal of Applied Economics and Business 
[18] Nikolaou, K. (2009). Liquidity (Risk) Concept: Definitions and Interactions. European Central Bank, EuroSystem. Working Paper Series No 1008.

[19] OeNB \& FMA. (2004). Guidelines on Credit Risk Management, Credit Approval Process and Credit Risk Management Oesterreichische Nationalbank (OeNB) in Cooperation with the Financial Market Authority (FMA). Vienna, Austria.

[20] Oldfield, G. S.,\& Santomero,A. M. (1997). Risk Management in Financial Institutions, Sloan Management Review, Vol. 39 No. 1, pp. 33-46.

[21] Oxford Dictionary. (2005). Compact Oxford Dictionary, Thesaurus, and Wordpower Guide. Oxford University Press.

[22] Paudel, Gyanendra Prasad. (2019). Credit Risk Management in Nepalese Cooperative Societies, Aashish pauel,1st ed. Kathmandu.

[23] Paudel, GP \& Khanal, S. (2015). Determinants of Capital Adequacy Ratio (CAR) in Nepalese Cooperative Societies, SSRN 2647541.

[24] Paudel, GP \& Khanal, S. (2016). A study of liquidity and interest spread in Nepalese cooperative societies, http://www.sciencepublishinggroup.com/j/ijefm doi: 10.11648/j.ijefm. 20160406.11 ISSN: 2326-9553 (Print); ISSN: 2326-9561 (Online)

[25] Penman, S. (2009). Financial Statement Analysis \& Security Valuation,4th ed. New York: McGrawHill/Irwin.

[26] Project Management Institute. (2008). A Guide to the Project Management Body of Knowledge, (PMBOK Guide), Fourth Edition, ANSI/PMI 99-001-2008, pp. 273-312.

[27] Rufai, A. S. (2013). Efficacy of Credit Risk Management on the Journal of Performance of Banks in Nigeria A Study of Union Bank PLC (2006-2010). Global Management and Business Research Administration and Management Volume 13 Issue 4 Version 1.0

[28] Santomero, A. M. (1997). Commercial Bank Risk Management: an Analysis of the Process, Financial Institutions Center. The Whartoon School, pp. 1-51.University of Pensilvenia.

[29] Six, K.,\& Kowalski E. (2005). Developing a Risk Management Strategy: Five Steps to Risk Management and Nonprofit and Caritable Organizations. Imagine, p.2. Social Planning Council for the North Okangan.

[30] Shafiq, A.,\&Nasr,M. (2010). Risk Management Practicollowed by the Commercial Banks in Pakistan. International Review of Business Research papers Vol. 6. No. 2. July 2010 pp. $308-325$.

[31] Sharma, S. R. (2006).Cooperative Movement: A People Based Development Approach, Its Role in Nepalese Economy. An Unpublished PhD Thesis. Jamia Millia Islamic Central University

[32] Thapa, K. (2012). Financial Institution \& Markets. Asmita Books Publishers \& Distributors Pvt. Ltd. 2069, Chap. 3 Pp. 88 - 222.

[33] UNESCO. (2010). Risk Management Training Handbook. Bureau of Strategic Planning. United Nations Educational, Scientic and Cultural Organization (UNESCO).

[34] Wolf, H., \&Pant, (2002). A Hand Book of Social Science Research and Thesis Writing (Third ed.). Budddha Academic Publishers and Distributer. Kathmandu. 